\title{
Learning Region and Performance of Pharmaceutical Industry: Evidence from Two Indian States
}

\author{
Tareef Husain \\ Centre for Studies in Economics and Planning, Central University \\ of Gujarat, Gandhinagar
}

\begin{abstract}
In the extent literature, availability of critical regional and technology-based factors have been recognized as the constituents of learning region which in turn lead to the rising performance of enterprises located in the region. These regional factors subsume sub-national policies, vertical industries, knowledge institution, skill, demand and infrastructural factors. Pharmaceutical industry is one of the knowledge-intensive industries, which is theoretically believed to be performed better in a learning region. The present study takes into account two Indian states namely, Gujarat and Himachal Pradesh and describes the status of pharmaceutical industry in the light of learning region. The descriptive explanation based on time series data for the last two decades revealed that the rising trends of pharmaceutical industry in the state of Himachal Pradesh, sourced by the conducive policy supports, rising share of chemical industry, rising enrolements in higher education and availability of good infrastructure. On the other hand, despite encompassing considerable infrastructure, skilled labour, knowledge and demand, Gujarat has reported constant or marginally declining trends of pharmaceutical industry, in terms of number of units, output and employment during last decade.
\end{abstract}

Keywords: Learning region, Performance, Pharmaceutical industry, Indian states, Technological factors, Regional factors.

\section{INTRODUCTION}

7 he concept of learning region defines in terms of creation of knowledge and ideas through delivery of fundamental environment with the help of combined learning and co-opetition among different firms, institutions and government in a region. The growing literature on learning region (e.g. Florida, 1995; Rutten and Boekema, 2007) argued that the prophecy of innovation is not only confined to the development and adoption of new technologies and processes, but to encourage the local and sectoral interaction among various institutions and firms. Pharmaceutical industry is a knowledge-based industry, where availability of critical regional factors have been identified as the determining factors to its performance (Mariussen, 2001; Asheim and Isaksen, 2002; Wolfe, 2003). These critical regional factors subsume knowledge institutions, skilled labour, demand, and infrastructure (Pradhan, 2011; 2013).

Indian pharmaceutical industry has grown drastically after the introduction

Journal of Technology Management for Growing Economies

Vol. 6, No. 2

October 2015 pp. $45-64$

\section{ChIKARA 司 UNIVERSITY}

C 2015 by Chitkara University. All Rights Reserved. 

the economic reforms of 1990s intensified the growth of Indian pharmaceutical industry (Chaudhuri, 1997). But, as the product patent regime re-introduced in India in the year of 2005, performance of pharmaceutical industry has increased in terms of efficiency, due to exit of inefficient and unproductive firms from the industry (Neogi, et.al, 2014). Introduction of product patent regime brought the Indian firms in direct competition with the foreign firms, aftermath many small firms in the industry either consolidated with others or discontinued their production.

The recent study on performance of Indian pharmaceutical industry is done by Neogi et al., (2014), concluding that the Indian pharmaceutical industry in some of the Indian states performed well in terms of efficiency, due to the special facilities provided to those states. The present study takes one state from the "getting special facilities states" (viz. Uttarakhand and Himachal Pradesh) i.e. Himachal Pradesh and compare it with an older industrialised state, namely, Gujarat. This study assesses the pharmaceutical industry in these two states, based on the theoretical framework of learning region.

The states of Gujarat and Himachal Pradesh (HP) together contribute to the Indian pharmaceutical industry with one-fifth share, in term number of pharmaceutical firms in India, during 2006-110 (Figure 2 and 1). Whereas, Gujarat alone contributes to Indian pharmaceutical industry by 15.4, 14.7 and 12.1 per cent in terms of number of factories, output and value added respectively, in the period of 2006-11 (Figure 2). On the other hand, Himachal Pradesh constitutes the Indian pharmaceutical industry in terms of above indicators with, 5.3, 10.1 and 14.6 per cent respectively (Figure 1).

The next section of the study covers conceptual framework for the study, whereas the third section deals with various components of learning region in the states of Gujarat and Himachal Pradesh. Section 4 reveals the performance of pharmaceutical industry in terms of number of factories, output, net value added, employment, gross capital formation and export. Section 5 concludes the study.

\section{CONCEPTUAL FRAMEWORK}

Learning region has its root in the 1890s, when Marshall was advocating the concept of 'industrial district' (Exploitation of complementarities by/ from vertically-associated firms). Since ever, various concepts dealing with the interaction of firms, firms/institutions, firm/government, etc. have been developed over the last two or three decades, including, "learning region" (Florida, 1995; Morgan, 1997); "cluster" (Porter 1990, 1998, 2000; Maskell, 2001; Iammarino and McCann, 2006); "innovative milieu” (Maillat, 1998);

Journal of Technology Management for Growing Economies, Volume 6, Number 2, October 2015 
"regional innovation systems" (Cooke et al., 1997; Cooke, 2001, 2004; Asheim and Isaksen, 2002; Malberg and Maskell, 2002; Wolfe, 2003).

With the starting of 21 st century, the importance of knowledge economy and knowledge-based firms is increasing faster than ever, where innovation has a crucial role to play. Schumpeter, the pioneer advocate of innovation in his earlier work assigned entrepreneur as the agent of innovation, but later it has been recognised that the innovation is a routine process performed by the R\&D organisation (Freeman et al., 1982). Further, it has been recognised that innovation is the interactive process among firms, firms and institutions of a region which lead to faster growth of firms located in these regions (Florida, 1995; Rutten and Boekema, 2007).

The growing literature on regional innovation system (Cooke, et al., 2000) suggests that the increased amount of expenditure on science and technology (including educational and research institutions) lead to the rise in efficiency of various inputs. Generally, it has been observed that the same input at different places produce different levels of output might be due to the availability of infrastructure, government support, availability of skill etc. According to Faggian and McCann (2009), the inflow of skilled labour in Britain determined the higher performance of knowledge-based industries. Similarly, the rapid rise of indigenous strength in the Indian software industry is intimately associated to the rise of Bangalore a city with higher skill (comprises of enrolements on higher education) that accounts for nearly 15 per cent of India's higher education enrolments (Joseph and Abraham, 2009).

The literature on new economic geography claimed that firms are suppose to locate in a region with higher demand, as it leads to the exploitation of scale economies and minimization of transport costs (Krugman 1991; Amiti, 1998). The ambience for interactive learning and innovation will be higher for a firm if it is situated in a region with larger demand, attracting a greater number of firms. Therefore, regions with well-built demand offer a wide variety of formal and informal inter-firm connections and dynamics of competition, synergies and complementarities. A study has done by Desmet et.al. (2010), shows that the larger markets lead to the increase in competition and facilitate the process innovation.

In the year 2000, OECD recognised the importance of learning economy and initiated a project called Cities and Regions in the New Learning Economy (OECD, 2000). This project was mainly concentrated to the economic benefits arising out in a learning region. The project was aimed to renovate the industrial society into a society where production and dissemination of products is largely based on the interaction of local players. The policy implications to local government were that there is a need to promote innovation and productivity
Learning Region and Performance

Journal of Technology Management for Growing Economies, Volume 6, Number 2, October 2015 
Husain, T. at local level through conducive environment for the productive activities.

- Conducive Government Policies

- Stock of Knowledge

- Favourable Infrastructure

- Suffiecient Demand

- Availability of Skill

- Complementarities

Figure: 1

Source: Drawn by author.

On the basis of extant literature over learning region and other related concepts, the figure above has been drawn. Figure 1 reveals the various components of a learning region, which are together lead to the conducive environment of doing business for the firms located in the same region.

\section{COMPONENTS OF LEARNING REGION}

The various components of learning region with reference to two Indian states namely, Gujarat and Himachal Pradesh are discussed in detail in the following sub-sections:

\section{Central Government Industrial Policy and Schemes}

Since independence, Indian Government has continuously been setting up committees and implementing policies to remove the industrial disparities among Indian states. The first effort made on the part of Government was in 1968, where Indian Government set up 'Pande Committee' under the Planning commission to spell out the criteria for recognising backward district among Indian states. Similarly, in the same year 'Wanchoo Committee' was set up to look into the matters of financial concessions and incentives necessary for the development of industrial backward areas of the Country.

In the year 1987, National Institute of Public Finance and Policy framed a study to examine the effects of financial incentives on the development of industrially backward areas, this study reported positive effects of incentives on development of industries, and this was the rationale behind the full tax holiday for the initial five years in the backward areas (Singhi 2012).

There are many schemes introduced by government of India, such as, 'Central Investment Subsidy Scheme 1971', 'Growth Centres 1988', and 'industrial Infrastructure Upgradation Scheme 2003' etc. to improve the

Journal of Technology Management for Growing Economies, Volume 6, Number 2, October 2015 
conditions of industrially backward areas. The recent national policy providing incentives and concessions to the backward states is as follows:

New Industrial Policy and other Concessions for the State of Uttaranchal and the State of Himachal Pradesh

Government of India on $7^{\text {th }}$ January 2003 announced 'New Industrial Policy and other Concessions for the State of Uttaranchal and the state of Himachal Pradesh', with the objective of development of industries and employment in these two states. The Policy considered Himachal Pradesh as one of the backward states in terms of industrialisation and pharmaceutical industry as one of the thrust industries to be promoted. Following are the incentives and concessions provided under the 'New Industrial Policy and other Concessions for the State of Uttaranchal and the state of Himachal Pradesh':

\section{Fiscal Incentives to the New and Existing Units}

The established industrial units or the new units planning to establish in Industrial Estates, Industrial Infrastructure Development Centres, and Growth Centres etc. are entitled to the following exemptions:

a. 100 per cent outright excise duty exemption for the period of ten years from the date of commencement of commercial production.

b. 100 per cent of income tax exemption for the starting five years, after that 30 per cent for companies and 25 per cent for other than companies for rest of the five years to the whole state of Himachal Pradesh from the date of commencement of commercial production.

c. All the new units locating in the notified location are eligible for the capital investment subsidy at 15 per cent of their investment in plant and machinery, subject to a ceiling of INR 30 lakh. The existing units are also eligible to this scheme on their expansion.

d. Pharmaceutical industry has listed as one of the thrust industries in the policy documents, where it is entitled to all of the above concessions, viz. excise duty exemption, income tax exemption and capital investment subsidy. These incentives provided to new as well as existing pharmaceutical units on their substantial extension.

\section{Development of Industrial Infrastructure}

Following are the sub-schemes and concessions provided under the scheme of Development of Industrial Infrastructure:

a. Provision for the INR 10 Crores under the scheme of Growth Centre

Journal of Technology Management for Growing Economies, Volume 6, Number 2, October 2015
Learning Region and Performance 
Husain, T.

Scheme, later, the limit was raised to 15 Crores.

b. Under the scheme of Integrated Infrastructure Development Centres (IIDC), Government provides required infrastructure support with the help of SIDBI.

The above schemes and concessions provided by the Government are meant for the industrially backward states, where Himachal Pradesh falls in that category. Now, apart from the Central Government Policies, various state Governments are also formulating policies to promote the industrial development in their own states.

The policies and schemes adopted by Gujarat and Himachal Pradesh to promote industrialisation and especially pharmaceutical industry are as follows:

\section{Industrial Policies of Gujarat}

Gujarat is one of the major industrially developed states in India; this state provides various taxes related and other incentives to the private sector, so that the process of industrialisation could get intensified in the state. One of the main incentives provided by Gujarat government was sales tax exemptions, this incentive provided to private sector till 2000, after that the government shifted its strategy from tax related incentives to the cost related incentives i.e. subsidies on investment, establishment etc. The very reason for the shifting of incentive strategy from tax related to the cost related was that of competition, to remove the unnecessary competition among different states, various states agreed to keep the similar kind of incentives. Gujarat was the first state to remove the sales tax exemptions.

\section{Industrial Policy 2000}

Gujarat Industrial Policy (2000), provided various incentives to the private sector such as, interest subsidy upto 5 per cent to the new units and existing small units, RandD subsidy to the industrial cluster upto Rs. 50 million for the establishment of general institutions to improve the quality of product, technology, technical skills etc. Similarly, a subsidy@50 per cent of expenses upto Rs. 0.5 million for filing patents on the research by industries or RandD institutions has been introduced under the policy. There are also other subsidies and concessions such as Capital Subsidy, Quality Improvement Assistance, Land Provision, and Air freight Subsidy etc. to promote the industrialisation process in the state.

\section{Industrial Extension Bureau}

Government of Gujarat recognised the importance of industry and Universities/

Journal of Technology Management for Growing Economies, Volume 6, Number 2, October 2015 
Institutions collaboration to promote the RandD in the industrial sector. Government of Gujarat assigned the key role to the Industrial Extension Bureau to deal with matters related to University/Institutions collaboration with industries.

\section{Industrial Policy 2003}

In the Industrial Policy (2003), Government of Gujarat adopted a pro-active approach and promoted the environment of free market for the development of industrial sector of the state. The main focus was given to providing information to the entrepreneur related to the availability of infrastructure in different location, rules and regulations, incentives etc. At the state level, iNDEXTb has been functioning to act a single point contact for all the information needs of an entrepreneur since last 25 years.

The DICs (District Industrial Centres) were reincarnated to provide the basic information to the entrepreneur; the name was changed to DIDC (District Industrial Development Centre). There are various centres to look into the matter of information dissemination such as District Industries Development Centre (DIDC), Industries Commissionerate, Inter Departmental Committee, and Gujarat Industrial Promotion Board (GIPB). Apart from these, SEZ Cluster development strategy was also adopted by the Gujarat Government. In the Industrial Policy 2003, the emphasis was also given to the investment from NRIs in the form of FDI. This Industrial Policy also came with the reforms in taxation system where, the stamp duty levied on industrial loans reduced to INR 2 lakh irrespective of the size of the loan, the sales tax slabs reduced from 17 to 6 , levy of additional tax i.e. surcharge also removed that was about 10 per cent earlier.

\section{BT Policy 2007-12}

In the year 2007 Government of Gujarat announced a bio-technology policy (BT Policy 2007-2012) as the state realised the importance of knowledgebased industries. Gujarat Government in its BT Policy 2007 announced various incentives to the Biotechnology units but excludes the manufacturer of pharmaceutical products like, formulation, Bulk Drug, Active Pharmaceutical Ingredients from taking the benefits of various incentives. But some incentives may be utilised by the pharmaceutical units, such as creating favourable infrastructure like, R\&D institutions, cluster development, power etc.

\section{Industrial Policy 2009}

The Industrial Policy (2009), was announced by the government of Gujarat to provide the broad outline to the industries, over the environment of

Journal of Technology Management for Growing Economies, Volume 6, Number 2, October 2015
Learning Region and Performance 
business in the state. This Industrial Policy, provides various incentives to the new and existing enterprises, such as Interest Subsidy upto 7 per cent to the small units and 2 per cent to the large units for the period of 5 years, the maximum amount to large units is 50 lakh and to small units 25 lakh, providing Infrastructure Facilities like internal roads, water distribution, power distribution, communication facilities etc. Another is providing Assistance in setting up of Common Facilities i.e. facilities used by the units for testing raw materials, semi finished goods and other materials used for the development of new technologies, process, design, upto 80 per cent of total expenditure which is limited to the 10 Crores for the cost of plant and machinery equipment, electrification etc. Apart from the above incentives there are other concessions like, Assistant for Common Effluent Treatment Plant (CETP), Assistance for Centre of Excellence. These incentives are provided by the Government of Gujarat with the help of State Level Approval Committee (SLAC).

\section{Industrial Policies of Himachal Pradesh}

Government of Himachal Pradesh (HP) has been announcing its Industrial Policies, keeping in due consideration the importance of industrial sector in the overall economy of state. The state has been providing various incentives, concessions, subsidies etc. to the industrial sector so that the state could attract more and more industries and investment not only in the developed regions but also in less developed regions of the state.

There are various policies and schemes adopted by the Government of Himachal Pradesh, which are as follow:

\section{Industrial Policy Guidelines 1999}

In its Industrial Policy Guidelines (1999), HP Government recognised that the existing infrastructural facilities are not sufficient to attract investment and industries into the state and in this era of globalisation the state's attitude and approach toward investors play a significant role to promote industrialisation in the state. In this Industrial Policy guidelines HP government focused on various requirements for the promotion of investment and industries, such as improvement of infrastructure, simplification and rationalisation of tax system, promotion of FDI and export, R\&D and modernisation of existing units, promotion of industrial cells, new procedure of land transfer and special incentives to the thrust areas and knowledge-based industries.

\section{Industrial Policy 2004}

Government of Himachal Pradesh in its Industrial Policy (2004) included pharmaceutical industry as one of the thrust industries to be developed. Special

Journal of Technology Management for Growing Economies, Volume 6, Number 2, October 2015 
incentives were being provided to the new industrial units, such as Exemptions from the Payment of State Excise Duty for 7 years in area B and C, total exemptions from the payment of Electricity Duty for the period of 10 years, Interest Subsidy at 5 per cent per annum on term loan. In the area ' $C$ ' i.e. Tax free Zone, all the industrial units set up shall be exempted from state taxes and duties.

The incentives and subsidies in Himachal Pradesh, provided to the various industrial units, such as Interest Subsidy to the small units in the priority sector, capital investment subsidy for units being set up in the Priority sector, GST exemption and CST at concessional rates, procurement of raw materials at $1 \%$ GST, allotments of plots and sheds at reasonable prices/rates in industrial areas and estates, Project specific special package etc.

In the Industrial Policy (2004), Himachal Pradesh government introduced some power incentives to the new industrial units locating in the state. The new industrial units shall be charged a concessional rate of Electricity Duty at the rate of 10 paisa per unit for a period of 5 years from the date of commencement of commercial production in category B and C areas only. The sales tax incentives like, exemption from payment of C.S.T/G.S.T. for 10 years from the date of their commencement of production in the Tax Free Zone. There was a provision of deferment of General Taxes up to 100 per cent to the new industrial unit, for 8 years in area ' $\mathrm{B}$ ' and 5 years in area ' $\mathrm{A}$ '.

There are other incentives like, 100 per cent subsidy on carriage and installation cost of plant and machinery in the state, Special Investment Subsidy on fixed capital assets up to 10 per cent with a limit of INR 1 lakh. As the R\&D plays a major role now days, Government of Himachal Pradesh had been providing reimbursement of cost involve in the R\&D up to 50 per cent or INR 10 lakh.

\section{New Incentive Rules 2004}

In the year 2004 'New Incentive Rules' were adopted by Himachal Pradesh with the objective of adopting the strategies to promote the existing investment climate in the state. As a result, emphasis was given on the improvement in the existing infrastructural situation, improvement in the various incentives and concessions and rules and procedures which have the direct impact on the investment flows in the state. Promotion of industrial areas and estate had been one of the primary objectives of HP; these matters supervised by the agencies like Himachal Pradesh State Industrial Development Corporation and Himachal Urban Development Agency (HIMUDA) under the department of Industries itself.

Journal of Technology Management for Growing Economies, Volume 6, Number 2, October 2015
Learning Region and Performance 


\section{Husain, T. Stock of Knowledge, Skill and Complementarities}

Stock of knowledge, skill and complementarities are the major components of learning regions. The stock of knowledge proxied by number of patent applications and number of higher education institutions hold positive relation in attracting higher number of firms in a region as well as higher performance of firms (Freeman, 1987; Lundvall, 1992; Pradhan and Das, 2013). The comparison of stock of knowledge between Gujarat and Himachal Pradesh is shown in Table 1 and Table 2. It has been revealed that Gujarat is far ahead than Himachal Pradesh in terms of stock of knowledge over the last two decades. The patent applications are shown in Table 1, where Gujarat has reported increasing number of patent applications over the last two decades from 65 to 300 during the periods of 1995-98 to 2007-10; Whereas, Himachal Pradesh has reported negligible numbers of patent applications, viz. 4 in the period of 1995-98 and 8 during 2007-10.

Table 1: Average State level Technological Activities and Percentage Share of Related Industry

\begin{tabular}{|l|c|c|c|c|c|c|}
\hline \multirow{2}{*}{ Years } & \multicolumn{2}{|c|}{ Patent } & \multicolumn{2}{c|}{ Patent Intensity } & \multicolumn{2}{c|}{$\begin{array}{c}\text { Percentage Share of } \\
\text { Chemical Industry }\end{array}$} \\
\cline { 2 - 7 } & Gujarat & HP & Gujarat & HP & Gujarat & HP \\
\hline $\mathbf{1 9 9 5 - 9 8}$ & 65 & 4 & 0.49 & 0.29 & 12.4 & 11.2 \\
\hline $\mathbf{1 9 9 9 - 0 2}$ & 152 & 3 & 1.04 & 0.17 & 14.8 & 12.2 \\
\hline $\mathbf{2 0 0 3 - 0 6}$ & 227 & 9 & 1.16 & 0.39 & 14.3 & 17.7 \\
\hline $\mathbf{2 0 0 7 - 1 0}$ & 300 & 8 & 0.94 & 0.24 & 13.5 & 25.5 \\
\hline
\end{tabular}

Note: Patent intensity is the number of patent application per 100 billion GSDP.

Source: Author's calculation based on (a) various Annual Reports of the Controller General of Patents, Designs and Trade Marks, (b) various statements on State Domestic Product and reports of Annual Survey of Industries (ASI), CSO.

On the other hand, patent intensity (no. of patent applications per 100 billion GSDP) did not report as much differences between the two states as it is shown in terms of number of patent applications over the last two decades. Although, the difference has increased in terms of patent intensity in the two states, where Gujarat has reported almost two times higher patent intensity from Himachal Pradesh in the period of 1995-98, increasing to three times higher patent intensity during the period of 2007-10. The fact based on the number of patent applications reveals that innovative activities in the state of Gujarat are better than the state of Himachal Pradesh.

Journal of Technology Management for Growing Economies, Volume 6, Number 2, October 2015 
Table 2: Average Regional Knowledge Institutions and Skilled labour

\begin{tabular}{|l|c|c|c|c|c|c|c|c|}
\hline \multirow{3}{*}{ Years } & \multicolumn{3}{|c|}{ Knowledge Institutions } & \multicolumn{4}{c|}{ Enrolments } \\
\cline { 2 - 10 } & \multicolumn{2}{|c|}{$\begin{array}{c}\text { Numbers } \\
\text { Numbers Per } \\
1000 \text { sq. km. }\end{array}$} & \multicolumn{2}{|c|}{ Numbers } & \multicolumn{2}{c|}{$\begin{array}{c}\text { Numbers Per } \\
\text { Lakh } \\
\text { Population }\end{array}$} \\
\cline { 2 - 10 } & Gujarat & HP & Gujarat & HP & Gujarat & HP & Gujarat & HP \\
\hline $\mathbf{1 9 9 1 - 9 5}$ & 69 & 9 & 0.35 & 0.16 & 379836 & 58857 & 92 & 114 \\
\hline $\mathbf{1 9 9 6 - 0 0}$ & 92 & 14 & 0.47 & 0.25 & 491735 & 79834 & 119 & 154 \\
\hline $\mathbf{2 0 0 1 - 0 5}$ & 135 & 22 & 0.69 & 0.40 & 622717 & 107139 & 123 & 177 \\
\hline $\mathbf{2 0 0 6 - 1 0}$ & 258 & 29 & 1.32 & 0.53 & 943012 & 150111 & 186 & 247 \\
\hline
\end{tabular}

Note: Higher education institutions comprise of universities, deemed universities, institutions of national importance, research institutions, and colleges for professional education such as, engineering, technology and architecture, medical colleges (allopathic, Ayurvadic, Homeopathic and Unani).

Source: Authors estimation based on Annual Reports of Higher Education and Selected Educational Statistics, Department of Higher Education, MHRD.

In case of knowledge institutions, the two Indian states (Gujarat and Himachal Pradesh) reported the same sorts of trends and patterns, showing much wider differences in terms of absolute number of higher education institutions, but in relative terms (instt. Per 1000 sq. km) Gujarat has reported two to three times higher institutions than Himachal Pradesh over the last two decades.

Availability of skill in a region provides the enterprises efficient human resource which may in turn lead to the higher efficiency in the production process. Skill in a region plays positive role in determining the performance of firms located in the region (Porter, 1990; Sexenian 1996). Pharmaceutical industry is a knowledge-based industry where skill may play a significant role in determining the performance of pharmaceutical firms. Enrolment in higher education is taken as a proxy indicator for the availability of skill in the states of Gujarat and Himachal Pradesh. Table 2, reveals that Gujarat is far ahead of Himachal Pradesh in terms of absolute number of enrolements in the higher education, but in case of relative enrolments numbers (numbers per lakh population) Himachal Pradesh is in better position. This shows that Himachal Pradesh has higher skilled labour as a percentage of total population than Gujarat.

The complementarities provided by the vertically related firms in a region leads to higher performance of those firms located in the same region (Porter, 1998; Maskell, 2001). The vertically related firms also attract higher number of firms, as the new firms will be in a better position to reap the benefit pro-

Journal of Technology Management for Growing Economies, Volume 6, Number 2, October 2015
Learning Region and Performance 
Husain, T.

vided by other firms in the forms of raw materials, knowledge, skill etc. Table 1 , reveals the picture of vertically related firms of pharmaceutical industry i.e. chemical industry in the states of Gujarat and Himachal Pradesh. It is shown that in the early two periods (1995-98 and 1999-02) Gujarat was having higher percentage share of chemical industry than Himachal Pradesh. But in the last two periods (2003-06 and 2007-10) Himachal Pradesh has shown rising trends of percentage share of chemical industry in total number of industrial located in the state. In the last period of 2007-10 the percentage share of chemical industry is almost two times higher than the state of Gujarat.

\section{Infrastructure}

Adequate infrastructural facilities lead to the rise in productivity and efficiency of existing enterprises in a region, which in turn attract more enterprises in the region (Wheeler and Mody 1992; Asiedu and Lien 2004). Infrastructure facilities subsume, power, roads, teledensity, ports, finance etc. but the present study reveals the pictures of power, road and teledensity. The comparison of Gujarat and Himachal Pradesh in terms of infrastructure facilities is shown in the Table 3, revealing that both the states are almost equal to each other in overall infrastructural facilities.

Table 3: Availability of Infrastructure in the States of Gujarat and Himachal Pradesh

\begin{tabular}{|l|c|c|c|c|c|c|}
\hline \multirow{2}{*}{ Years } & \multicolumn{2}{|c|}{$\begin{array}{c}\text { Per capita Power } \\
\text { consumption kwh }\end{array}$} & \multicolumn{2}{c|}{$\begin{array}{c}\text { Density of roads } \\
\text { (length/sq } \\
\text { kms of geographical } \\
\text { area) }\end{array}$} & \multicolumn{2}{c|}{$\begin{array}{c}\text { Teledensity (per } \\
\text { 100 person) }\end{array}$} \\
\cline { 2 - 7 } & Gujarat & HP & Gujarat & HP & Gujarat & HP \\
\hline $\mathbf{1 9 9 5 - 9 8}$ & 484 & 312 & 2.26 & 1.92 & 2.56 & 3.22 \\
\hline $\mathbf{1 9 9 9 - 0 2}$ & 545 & 375 & 1.41 & 1.85 & 5.86 & 6.69 \\
\hline $\mathbf{2 0 0 3 - 0 6}$ & 713 & 544 & 1.36 & 2 & 16.00 & 17.65 \\
\hline $\mathbf{2 0 0 7 - 1 0}$ & 917 & 810 & 1.29 & 1.32 & 45.75 & 58.67 \\
\hline
\end{tabular}

Source: Indiastat.com.

In case of per capita power consumption Gujarat has been ahead of Himachal Pradesh, where Gujarat reported 484 kwh per capita power consumption in the period of 1995-98 which increased to 917 in the period of 2007-10. On the other hand, Himachal Pradesh reported $312 \mathrm{kwh}$ per capita power consumption, increasing to 810 in the period of 2007-10. As far as density of roads are concern, except the period of 1995-98 Himachal Pradesh remained ahead of Gujarat. In case of teledensity, both the states reported same kind of

Journal of Technology Management for Growing Economies, Volume 6, Number 2, October 2015 
trends i.e. increasing especially in the period of 2007-10.

\section{Demand Conditions}

Following the literature of new economic geography propounded by Krugman (1991), suggest that the size of local demand leads to the increasing returns to scale and lower transportation cost. As a result firms located in a region with higher demand conditions are supposed to be more productive in the region.

Table 4: Average Regional Demand Factors in the States of Gujarat and Himachal Pradesh

\begin{tabular}{|l|c|c|c|c|}
\hline \multirow{2}{*}{ Years } & \multicolumn{2}{|c|}{ GSDP (Rs. Lakh) } & \multicolumn{2}{c|}{ Per Capita GSDP } \\
\cline { 2 - 5 } & Gujarat & HP & Gujarat & HP \\
\hline $\mathbf{1 9 9 5 - 9 8}$ & 13171403 & 1499726 & 28423 & 26733 \\
\hline $\mathbf{1 9 9 9 - 0 2}$ & 14950564 & 1919499 & 29495 & 32013 \\
\hline $\mathbf{2 0 0 3 - 0 6}$ & 21933334 & 2526191 & 40386 & 39543 \\
\hline $\mathbf{2 0 0 7 - 1 0}$ & 32082023 & 3476511 & 55714 & 52092 \\
\hline
\end{tabular}

Note: Values of GSDP in Rs. Lakh; Both GSDP and PCI are at 2004-05 constant prices.

Source: Based on various Statements on State Domestic Product released by the Central Statistical Organization (CSO).

A comparison of demand conditions in the states of Gujarat and Himachal Pradesh is made in the Table 4. The Table suggest that in absolute terms (i.e. state domestic product) Gujarat is far ahead of Himachal Pradesh, whereas in relative terms (i.e. per capita state domestic product) Himachal Pradesh and Gujarat are growing simultaneously and did not report much dispersion over the last two decades.

\section{DATA ISSUES AND METHODOLOGY}

This study is based on various secondary data sources. The major source of data is ASI (annual survey of industries), from where the data on Indian pharmaceutical industry (Manufacture of Pharmaceuticals, Medicinal Chemicals and Botanical Products) is taken for the period of 1991-2011. Data is taken at three digit level on the basis of NIC-1987 code i.e. 304 during the period of 1991-92 to 1997-98 and at four digit levels, according to the NIC2008 code i.e. 2100 during the period of 2008-09 to 2010-11. During the period of 1998-99 to 2007-08, data is taken at unit-level from CSO (Central Statistical Organisation), Ministry of Statistics and Programme Implementation, because of non-availability of published data at state level. The data for chemical and other chemical products is also taken from ASI.

Journal of Technology Management for Growing Economies, Volume 6, Number 2, October 2015 

various Annual Reports of Higher Education and Selected Educational Statistics publish by Department of Higher Education under the Ministry Human Resource Development (MHRD), Government of India. Data on per capita GSDP and GSDP is taken from Statement on State Domestic Product released by Central Statistical Organisation (CSO). Patent data is taken from various Annual Reports, of the Controller General of Patents, Designs \& Trade Marks, while the data for infrastructure is taken from Indiastat.

This study takes into account various indicators to exhibit the performance of Indian pharmaceutical industry in the states of Gujarat and Himachal Pradesh. These indicators are, number of firms, output, net value added, gross capital formation, man days employees and export. The annual average growth rates have also been shown based on five years periods. The percentage shares of various indicators of pharmaceutical industry in Gujarat and Himachal Pradesh is also calculated from respective indicators at India level.

\section{PERFORMANCE OF PHARMACEUTICAL INDUSTRY IN GUJARAT AND HIMACHAL PRADESH}

Gujarat and Himachal Pradesh are the two leading states in the Indian manufacturing sector; and so is the depiction from Indian pharmaceuticals. The industrialisation in Gujarat is theoretically based on older agglomeration, whereas Himachal Pradesh is a newly emerged state in terms of industrialisation as well as pharmaceuticals.

It is revealed from Table 5 that in the period of 1991-95 there were only 9 pharmaceutical firms located in the state of Himachal Pradesh, these numbers increased marginally upto the period of 2001-05 and reached to 37, but suddenly, the number of firms increased to 237 in the period of 200611. The increasing numbers of firms in the period of 2006-11 are due to the concessions and incentives provided by Indian government under the "new industrial policy and other concessions for the state of Uttaranchal and the state of Himachal Pradesh' in the year 2003. Incentives and concessions provided to the new firms locating in backward regions minimises the initial cost of setting up plant, which in turn attract larger number of new firms in those region (Subrahmanya, 1995; Singhi 2012).

Simultaneously, complementarities provided by chemical industry (i.e. high percentage share of chemical industry (Table 1), skilled labour (Table 2) and good infrastructural facilities (Table 3) created the favourable environment for the business in the state of Himachal Pradesh. All these factors together contributed to the rising performance of Himachal Pradesh in terms of pharmaceutical industry. The extant literature on complementarities provided through backward and forward linkages of firms (Hirschman, 1963; Sexenian,

Journal of Technology Management for Growing Economies, Volume 6, Number 2, October 2015 
1996) illuminates that the concentration of vertically related firms in a regions lead to the easy accessibility of raw materials and various intermediate inputs, minimising the transportation and overall cost of production of enterprises, hence improving the performance of new and existing firms in the region. Similarly, skilled labour (Grossman and Helpman, 1994; Gashi, et al., 2014) and infrastructure (Asiedu and Lien, 2004) in a region are found to be playing major role in the performance of firms located in the region.

The annual average growth rate of number of pharmaceutical firms was quite higher (i.e. 77 per cent) for the state of Himachal Pradesh in the period of 2006-11. On the other hand, Gujarat was having almost three hundred times higher number of pharmaceutical firms than Himachal Pradesh in the period of 1991-95, but reducing to just three times higher number of firms in the period of 2006-11. The share of Himachal Pradesh and Gujarat in total number of Indian pharmaceutical firms is revealed in Figure 1 and 2. These figures depict that the percentage share of Himachal Pradesh in terms of number of firms increased by five times between the periods of 2001-05 to 2006-11. Whereas Gujarat has increasing share in terms of pharmaceutical firms till the period of 2001-05, but after that it has declined by four percentage points in the period of 2006-11.

It is to be noted that after 2000 s, the depiction of pharmaceutical industry in both the states changed dramatically, where Himachal Pradesh has been the gainer and Gujarat the loser (in relative terms). In the year 2005, Indian pharmaceutical industry came under the obligation of TRIPS agreement, where product patent regime was introduced. Simultaneously, in the same year new norms over the quality of pharmaceutical products have been introduced with the introduction of 'Good Manufacturing Practices of World Health Organisation' (WHO-GMP). Now, all Indian pharmaceutical units have to comply with the WHO-GMP, where it is found that many small units located in Gujarat could not comply with WHO-GMP as a result many units has been closed down or consolidated with other units (Neogi et al., 2014).

Table 5.1: Average Number of Factories, Output and Net Value Added

\begin{tabular}{|l|c|c|c|c|c|c|}
\hline \multirow{2}{*}{ Years } & \multicolumn{2}{|c|}{ Factories } & \multicolumn{2}{c|}{ Output } & \multicolumn{2}{c|}{ Net Value Added } \\
\cline { 2 - 7 } & Gujarat & HP & Gujarat & HP & Gujarat & HP \\
\hline $\mathbf{1 9 9 1 - 9 5}$ & 337 & 9 & 204539 & 2761 & 48647 & 827 \\
\hline $\mathbf{1 9 9 6 - 0 0}$ & 497 & 21 & 442534 & 26808 & 104296 & 8512 \\
\hline $\mathbf{2 0 0 1 - 0 5}$ & 660 & 37 & 660734 & 87816 & 147611 & 24216 \\
\hline $\mathbf{2 0 0 6 - 1 1}$ & 629 & 231 & 1375677 & 952766 & 323533 & 395359 \\
\hline
\end{tabular}

Journal of Technology Management for Growing Economies, Volume 6, Number 2, October 2015
Learning Region and Performance 
Husain, T.

Table 5.2: Annual Average Growth Rates

\begin{tabular}{|l|c|c|c|c|c|c|}
\hline & \multicolumn{2}{|c|}{ Factories } & \multicolumn{2}{c|}{ Output } & \multicolumn{2}{c|}{ Net Value Added } \\
\cline { 2 - 7 } & Gujarat & HP & Gujarat & HP & Gujarat & HP \\
\hline $\mathbf{1 9 9 2 - 9 5}$ & 11.0 & 8.5 & 28.0 & 110.0 & 46.3 & 55.8 \\
\hline $\mathbf{1 9 9 6 - 0 0}$ & 18.6 & 30.8 & 24.8 & 65.8 & 24.8 & 63.8 \\
\hline $\mathbf{2 0 0 1 - 0 5}$ & -6.2 & 14.2 & -1.0 & 31.4 & 9.4 & 41.0 \\
\hline $\mathbf{2 0 0 6 - 1 1}$ & 5.0 & 77.4 & 22.2 & 129.8 & 20.0 & 174.0 \\
\hline
\end{tabular}

Note: Values of Output and NVA in rupees lakh; HP stand for Himachal Pradesh.

Source: Reports of ASI (1991-92 to 1997-98 and 2008-09 to 2010-11) and Unit Level Data (1998-99 to 2007-08).

It is revealed in Tables 5 and 6 that in the period of 2001-05 Gujarat reported negative annual average growth rates (AAGRs) in terms of number of units, output, gross capital formation and man day's employees; but in terms of net value added Gujarat reported a healthy AAGR and further in terms of export Gujarat reported even healthier AAGR. This experience of Gujarat implies that only non-exporting, inefficient and sick firms had been closed down as those firms might not be abled to comply with WHO-GMP. This phenomenon refers to the celebrated concept of creative destruction, where the inefficient firm closed down and only efficient firms survive. Similarly, there is an emerging literature dealing with the firm specific characteristics (Bernard, et al., 2003; Melitz, 2003), explaining that in the changing macroeconomic environment only those of efficient and productive firms survive, whereas inefficient firms either closed down or consolidate with others.

The AAGRs reported by Himachal Pradesh in terms of all the indicators, (viz. number of pharmaceutical firms, output, net value added, gross capital formation, man day's employees and export) were highest in the period of 2006-11; Whereas, Gujarat has reported lowest AAGRs in terms of all indicators during the period of 2001-05.

Table 6.1: Annual Average of Gross Capital Formation, Man Days employees and Export

\begin{tabular}{|l|c|c|c|c|c|c|}
\hline \multirow{2}{*}{ Years } & \multicolumn{2}{|c|}{ GCF } & \multicolumn{2}{c|}{ Man Days } & \multicolumn{2}{c|}{ Export } \\
\cline { 2 - 7 } & Gujarat & HP & Gujarat & HP & Gujarat & HP \\
\hline $\mathbf{1 9 9 1 - 9 5}$ & 21279 & 829 & 9177 & 320 & 48.3 & 17.8 \\
\hline $\mathbf{1 9 9 6 - 0 0}$ & 42849 & 8903 & 12899 & 425 & 98.7 & 63.4 \\
\hline $\mathbf{2 0 0 1 - 0 5}$ & 45668 & 11303 & 15516 & 741 & 215.3 & 173.1 \\
\hline $\mathbf{2 0 0 6 - 1 0}$ & 93990 & 90008 & 20810 & 6602 & 516.2 & 394.5 \\
\hline
\end{tabular}

Journal of Technology Management for Growing Economies, Volume 6, Number 2, October 2015 
Table 6.2: Annual Average Growth Rates

\begin{tabular}{|l|c|c|c|c|c|c|}
\hline & \multicolumn{2}{|c|}{ GCF } & \multicolumn{2}{c|}{ Man Days } & \multicolumn{2}{c|}{ Export } \\
\cline { 2 - 7 } & Gujarat & HP & Gujarat & HP & Gujarat & HP \\
\hline $\mathbf{1 9 9 2 - 9 5}$ & 20.4 & 712 & 14.3 & 5.5 & 21.5 & 38 \\
\hline $\mathbf{1 9 9 6 - 0 0}$ & 65.5 & 151.2 & 13.5 & 8.9 & 6.5 & 16.7 \\
\hline $\mathbf{2 0 0 1 - 0 5}$ & -13.8 & 5.1 & -2.2 & 20.5 & 27.3 & 29.1 \\
\hline $\mathbf{2 0 0 6 - 1 0}$ & 68.1 & 622.3 & 12.4 & 88.5 & 24.2 & 28 \\
\hline
\end{tabular}

Note: Values of GCF in Rs. Lakh, Values of Man Days in Rs. thousand and Values of Export in US \$ million.

Source: Same as Table 1; Data for Export is taken from Pradhan and Das (2012).

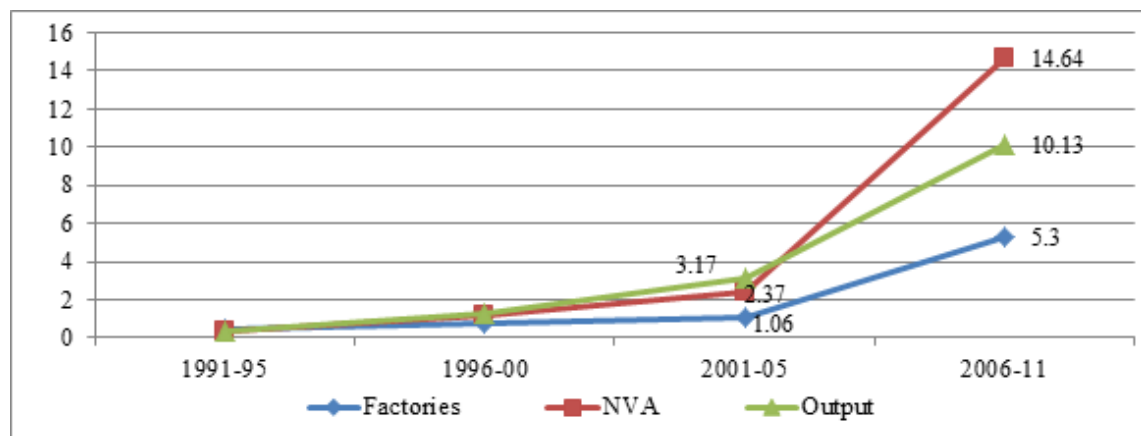

Figure 2: Percentage Share of Himachal Pradesh

Source: Calculated by Author from the above data source given in Table 1.

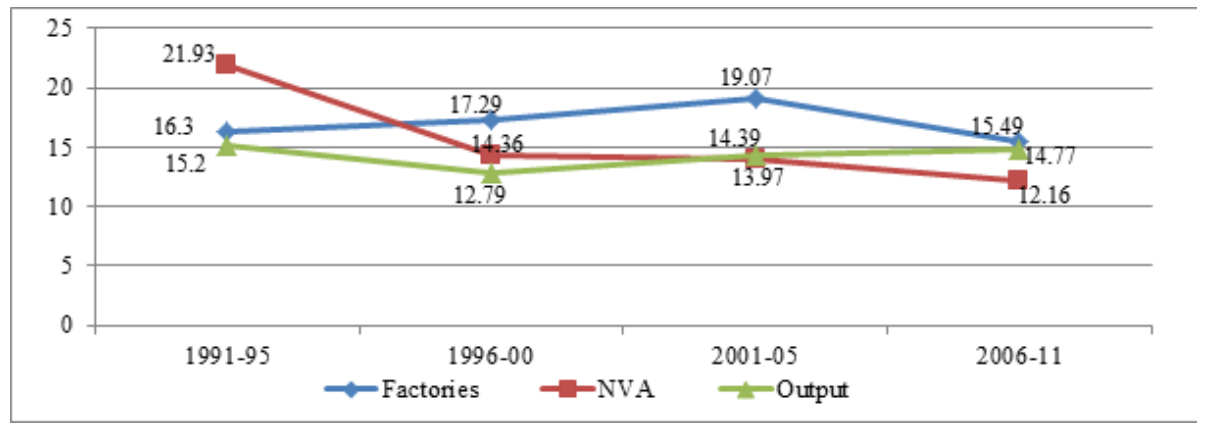

Figure 3: Percentage Share of Gujarat

Source: Calculated by Author from the above data source given in Table 1.

\section{CONCLUSION}

The decisiveness of interaction and synergies from critical local factors has 

stock of knowledge, skill, knowledge institutions, vertical industry, demand, infrastructure, government support and so on. The extant literature on learning region deems positive and significant impact of local factors on business activities, especially of knowledge-intensive business.

Pharmaceutical industry in the states of Gujarat and Himachal Pradesh has shown different paths of development. Gujarat reported rising tendency until the period of 1996-00; but declining trends during the period of 2001-05. Although number of units, output, gross capital formation, man days employees witnessed declining trends in the state of Gujarat but net value added and export continued to grow at a significant rate. This implies that due to the introduction of product patent regime and WHO-GMP, inefficient, sick and non-exporting enterprises closed down or consolidated with other firms in the state of Gujarat.

On the other hand, the state of Himachal Pradesh, which was nowhere till the early 2000s, reported drastic improvements during the period of 2006-11. The percentage share of firms located in Himachal Pradesh in total number of Indian pharmaceutical firms increased by five times and reach to around 5 per cent in the period of 2006-11 from 1 per cent in the period of 2001-05. The other performance indicators like, output, net value added, investment, employment and export have also shown the increasing trends in the same period. The drastic rise of pharmaceutical industry in the state of Himachal Pradesh has been related to the government support (from regional as well central), rise of vertical industry, availability of skill and favourable infrastructure. All these factors played influential role in the growth path of pharmaceutical industry in the state of Himachal Pradesh. In nutshell, Himachal Pradesh in the period of 2006-11 is the classic example of learning region.

\section{REFERENCES}

Amiti, M. (1998) 'New trade theories and industrial location in the EU: A survey of evidence' Oxford Review of Economic Policy, 14:2, pp. 45-53. http://dx.doi.org/10.1093/ oxrep/14.2.45.

Asiedu, E., and Donald, L. (2004) 'Capital controls and foreign direct investment', World Development, 32:3, pp. 479-490.

Asheim, B. T., and Isaksen, A. (2002) 'Regional innovation systems: The integration of local "sticky" and global "ubiquitous" knowledge', Journal of Technology Transfer, 27:1, pp. 77-86. http://dx.doi.org/10.1023/A:1013100704794.

Asiedu, E. and Donald, L. (2004) 'Capital controls and foreign direct investment', World Development, 32:3, pp. 479-490.

Bernard, A., Eaton, J., Jensen, J. B., and Kortum, S. (2003) 'Plants and productivity in international trade', American Economic Review, 93:4, pp. 1268-1290.

Chaudhuri, S. (2002) 'Economic reforms and industrial structure in India', Economic and Political Weekly, 37:2, pp. 155-162.

Journal of Technology Management for Growing Economies, Volume 6, Number 2, October 2015 
Cooke, P. (2001) 'From technopoles to regional innovation systems: The evolution of localized technology development policy', Canadian Journal of Regional Science, 24:1, pp. 21-40.

Cooke, P. (2004) 'Evolution of regional innovation systems - Emergence, theory, challenge for action', in Cooke P. (ed.), Regional Innovation Systems, (2nd, pp.1-18), London: Routledge.

Cooke, P., Boekholt, P., and Todtling, F. (2000) 'The governance of innovation in Europe', London: Pinter.

Cooke, P., Uranga, G. M., and Etxebarria, G. (1997) 'Regional innovation systems: Institutional and organizational dimensions', Research Policy, 26:4-5, pp. 475-491.

Desmet, K., and Parente, S. L. (2010) 'Bigger is better: Market size, demand elasticity, and innovation', International Economic Review, 51:2, pp. 319-333. http://dx.doi.org/10.1111/ j.1468-2354.2010.00581.x.

Faggian, A. and McCann P. (2009) 'Human capital, graduate migration and innovation in British regions', Cambridge Journal of Economics, 33:2, pp. 317-333. http://dx.doi.org/ 10.1093/ cje/ben042.

Florida, R. (1995) 'Toward the learning region', Futures, 27:5, pp. 527-536.

Freeman C., Clark J. and Soete L. (1982) 'Unemployment and technical innovation', London: Pinter.

Freeman, C. (1987) 'Technology policy and economic performance', London: Pinter.

Gashi, P., I. Hashi, and G. Pugh (2014) 'Export behaviour of SMEs in transition countries' Small Business Economics, 42:2, pp. 407-435.

Government of Gujarat (2003) 'BT Policy', Department of Industries and mines.

Government of Gujarat (2003) 'Industrial Policy', Department of Industries and Mines.

Government of Gujarat (2007) 'BT Policy', Department of Industries and Mines.

Government of Gujarat (2009) 'Industrial Policy', Department of Industries and Mines.

Government of Himachal Pradesh (1999) 'Industrial Policy', Department of Industries.

Government of Himachal Pradesh (2004) 'Industrial Policy', Department of Industries.

Government of India (2013) 'New industrial policy and other concessions for the state of Uttaranchal and the state of Himachal Pradesh', No.1 (10)/2001-NER, New Delhi: Ministry of Commerce and Industry, Department of Industrial Policy and Promotion.

Grossman, G. M., \& Helpman, E. (1994) 'Endogenous innovation in the theory of growth', Journal of Economic Perspectives, 8:1, pp. 23-44. http://dx.doi.org/10.1257/jep.8.1.23.

Iammarino, S., and McCann, P. (2006) 'The structure and evolution of industrial clusters: Transactions, technology and knowledge spillovers', Research Policy, 35:7, pp. 10181036.

Jha, R. (2007) 'Options for Indian pharmaceutical industry in the changing environment', Economic and Political Weekly, 42:39, pp.3958-3967.

Joseph, K.J., and Abraham, V. (2009) 'University-industry interactions and innovation in India: Patterns, determinants, and effects in select industries', Seoul Journal of Economics, 22:4, pp. 467-498.

Krugman, P. (1991) 'Increasing returns and economic geography', Journal of Political Economy, 99:3, pp. 483-499. http://dx.doi.org/10.1086/261763.

Lalitha, N. (2002) 'Indian pharmaceutical industry in WTO regime: A SWOT analysis', Economic and Political Weekly, 37:34, pp. 3342-3555.

Lundvall, B. (1992) 'National systems of innovation: Towards a theory of innovation and interactive learning' London: Pinter.

Maillat, D. (1998) 'From the industrial district to the innovative milieu: Contribution to an analysis territorialized production organizations', Discussion Paper: Université de Neutchatel.

Malmberg, A. and Maskell, P. (2002) 'The elusive concept of localization economies: Towards a knowledge-based theory of spatial clustering', Environment and Planning, 34:3, pp. 429449. http://dx.doi.org/ 10.1068/a3457. 
Husain, T.

\section{4}

Mariussen, A. (2001) 'Cluster policies - Cluster development?', Stockholm: Nordregio Report, No. $01 / 2$.

Maskell, P. (2001) 'Towards a knowledge-based theory of the geographical cluster', Industrial and Corporate Change, 10:4, pp. 921-944. http://dx.doi.org/10.1093/icc/10.4.921.

Melitz (2003) 'The impact of trade on intra-industry reallocations and aggregate industry productivity', Econometrica, 71:6, pp. 1695-1725. http://dx.doi.org/10.1111/14680262.00467.

Morgan, K. (1997) 'The learning regions: Institutions, innovation and regional renewal', Regional Studies, 31:5, pp. 491-503. http://dx.doi.org/10.1080/00343409750132289.

Neogi, C, Kamiike, A, and Sato, T. (2014) 'Factors behind the performance of pharmaceutical industries in India', Economic and Political Weekly, 49:52, pp. 81-89

OECD (2000) 'Small and medium-sized enterprises: Local strength, global reach', Paris.

Porter, M. E. (1990) 'The competitive advantage of nations', London: Basingstoke Macmillan.

Porter, M. E. (1998) 'Clusters and the new economics of competition', Harvard Business Review, 76:6, pp. 77-90.

Porter, M. E. (2000) 'Location, competition, and economic development: Local clusters in a global economy', Economic Development Quarterly, 14:1, pp. 15-34. http://dx.doi. org/10.1177/089124240001400105.

Pradhan, J. P. (2011) 'Regional heterogeneity and firms' RandD in India', Innovation and Development, 1:2, pp. 259-282.

Pradhan, J. P. (2013) 'The geography of patenting In India: Patterns and determinants', Munich Personal RePEc Archive, No. 50595.

Rutten, R.P., and Boekema, F.W.M. (eds.) (2007) 'The Learning Region: Foundations, State of the Art, Future, Cheltenham, UK: Edward Elgar.

Sexenian, A. L. (1996) 'Inside-out: Regional networks and industrial adaptation in Silicon Valley and Route 128', Journal of Policy Development and Research, 2:2, pp. 41-60.

Singhi, M.C. (2012) 'Report on the role of incentives in the development of industrially backward States/UTS', Ministry of Commerce and Industry, Office of the Economic Advisor, Paper No. 39.

Subrahmanya, M.H.B. (1995) 'Reservation policy for small-scale industry: Has it delivered the goods', Economic and Political Weekly, 3:21, pp. 51-54.

Venkatesan R., and Varma S. (2000), 'Study on policy competition among states in India for attracting direct investment', National Council of Applied Economic Research, New Delhi.

Wheeler, D., and Ashoka M. (1992) 'International investment location decisions: The Case of U.S. Firms', Journal of International Economics, 33:1-2, pp. 57-76.

Wolfe, D. (2003) 'Clusters old and new: The transition to a knowledge economy in Canada's regions', Kingston: Queen's School of Policy Studies.

Tareef Husain, Centre for Studies in Economics and Planning, Central University of Gujarat, Gandhinagar. Email: tareefhussain.amu@gmail.com.

Journal of Technology Management for Growing Economies, Volume 6, Number 2, October 2015 